\title{
The Diglossic Relationship between Shona and English Languages in the Teaching and Learning Situation in Zimbabwe Secondary Schools.
}

\author{
Chimhenga Sylod ${ }^{1}$, Dr Ester Chivhanga ${ }^{2}$, \\ ${ }^{1}$ Lecturer, Centre for Student Management, Zimbabwe Open University, Zimbabwe \\ ${ }^{2}$ Principal Lecturer, United College of Education, Zimbabwe
}

\begin{abstract}
The research has endeavoured to highlight the problems of the diglossic relationship of Shona and English in the teaching and learning situation in Zimbabwe secondary schools. It focused on how English as a high variety language has adversely affected the performance of learners writing 'O' level Shona examinations in Secondary school. The research also sought to confirm whether teachers and learners of Shona in Zimbabwe secondary schools look down upon their language and show negative attitude towards it.

Finally, the use of English in the teaching of Shona, the less hours allocated to Shona, the low esteem of Shona vis-à-vis the dominance of English and the association of English with social mobility impact on the attitude of students towards Shona as a subject. This linguistic attitude coupled with orthographic problems causes low passes in Shona at 'O' level. Hence, one proposes, language awareness campaigns, use of Shona in the teaching of practical criticism and grammar and that the government gives value to Shona and other African languages by making them a requirement as working languages for people employed in the public sector.
\end{abstract}

Keywords: Language planning, diglossic, language policy, medium of instruction, African languages.

Accepted Date: 24 June 2013

\section{Introduction And Background To The Study.}

The area of this research is Sociolinguistics with a focus on the diglossic relationship between Shona and English languages in Zimbabwean secondary schools. This paper focused on how English as a high variety has affected the teaching and learning of Shona, a low variety language, at secondary school level.

Shona is one of the indigenous languages of Zimbabwe and is spoken by about $75 \%$ of the total population (Chimhundu 1993). It is taught in Zimbabwe from primary school level up to university. What worries advocates of the indigenous languages is the fact that in Zimbabwe secondary schools the medium of instruction for Shona as a subject is Shona but the teachers make use of English as a medium of instruction in teaching concepts such as Shona grammar. The reason for this abnormal situation of teaching Shona using English as a medium of instruction may be a result of colonial and post colonial language policies that were prevalent in the country (Gudhlanga and Makaudze 2005). In her article Dube (1997) also concluded that the underdevelopment of Shona hinders its use in areas such as the teaching and learning of Shona grammar and literary criticism. This may be influencing the performance of learners writing Shona at 'O' level in Zimbabwe secondary schools. The teachers and learners of Shona have looked down upon their language and have a negative attitude towards it. It is against this background that this paper highlights the problems of the diglossic relationship between Shona and English languages in the teaching and learning situation in Zimbabwe secondary schools.

II. The Historical Development Of Learning And Writing Of Shona In Zimbabwe Schools.

Records indicate that English people made initial contact with Southern Africa prior to the period of formal British Colonisation of the area (Silva 1995). From the $16^{\text {th }}$ Century onwards, for instance, English explorers and traders who visited the region began to introduce vocabulary describing the land and its people. The explorers learned the language and customs of the local people.

During the $16^{\text {th }}$ Century the Christian missionaries from several different denominations and nationalities established missions in the Shona speaking areas of Zimbabwe. According to Chimhundu (1992) and Magwa (2007) each of the missionary groups proceeded on its own to generate proselytizing literature to carry out its own mission. Partly because these missions worked in different dialectal areas, but mainly because these missionaries lacked sophistication, they imposed their native linguistic traditions on the Shona Language 
and relied on interpreters who were not fully proficient in Shona and English. As a result different written variations of Shona evolved in each of the mission areas suggesting that there was greater diversity within Shona than actually existed. (http://www.msu.edu/ dwyer/LgDialPr.htm). These missionaries differed in their choice of letters to mark sound spellings, word divisions and word choices as agued by Magwa (2007: 22). This written variation of Shona may have created problems of spellings of Shona words in the teaching of Shona as a subject in Zimbabwean secondary schools up to the present day.

Representatives of the different missions, having failed in their own attempt to develop a common system of writing Shona, commissioned the South African linguist, C. M. Doke, to undertake a dialect survey in 1929 and make recommendations about a common writing system. Doke (1931) found six different dialect groups of the language that he dubbed 'SHONA'. These consisted of Korekore, Zezuru, Manyika, Karanga, Ndau and Kalanga. Doke's Committee composed of representatives from some but not all of the dialects involved. Two dialects were not represented at all, that is, Korekore and Kalanga. The same person represented Manyika and Ndau. Such a representation had two major consequences: when differences in vocabulary occurred the commission relied most heavily on Zezuru and to a lesser extent on Karanga, and Kalanga was completely ignored. (http://www.msu.edu/ dwyer/LgDialPr.htm).

Chimhundu (1992) points out that this merely reflected the degrees to which each dialect was represented on the commission. As a result of this mission activity and the subsequent Doke commission, these dialects were crystallised in the European mould as a single language with a common literary form and a common Shona. This development took place without any significant participation of the Shona speaking population.

The missionaries did not "have the necessary linguistic or phonetic training; they saw 'tribes' everywhere and equated these tribes with dialect or languages (Chimundu 1992:100)". This resulted in a divergent system of spellings because wrong associations were made between sound and symbol and making reference only to Roman letters. Doke (1931) based his spelling system on the speech sounds found in Zezuru dialect because the dialect occupied a central position in regard to other groups of dialects found in the country. Further confusion was added to this variation in spelling by the imposition of a conjunctive system of word division which was based on rough translations of individual Shona morphemes, particularly substantive stems to correspond with whole words in English as highlighted by Chimhundu (1992), Magwa (2007) and Dube (2000). Because the early missionaries were guided by elements of meaning rather than by Shona phonological rules, they failed to recognize that Shona word division was marked by penultimate length, or relative prominence of the last but one syllable in each word. Mkangamwi (1975:204) argues that Shona has a system of word division based on the overriding principle of penultimate accent". However, the Doke commission had stressed that Shona has a natural word division; it did not divide the words according to the divisions in the English translations.

Mkangamwi (1975) also argues that $80 \%$ of the Shona orthography shows a one to one correspondence with the spoken language. Because of this close connection the teaching of reading in Shona is very easy. Dube (2000) points out that the teaching of reading in Shona may be very easy as Mkangamwi puts it but many Shona learners have problems when it comes to reading Shona aloud. Most of the learners, when reading Shona aloud, do not do so fluently.

English has always been a language with a higher status than Shona since the nineteenth century when Zimbabwe was colonised by the British. Adebija (1994:30) points out that European languages, for example, English, were imposed on colonised territories of Africa and many Africans looked upon the European languages as the master's language and yearned to learn them. The territorial conquest of Rhodesia (now Zimbabwe) by the British identified English as the language of the state (Cristal 1996: 29). Linguistically this meant that the use of English became a powerful national symbol. English functioned as a lingua franca and was a primary language of government, business and commerce. Educationally it was and still is a compulsory subject in all schools and is the preferred medium of instruction in most school and tertiary institutions. In colonial days English was typically seen as the language of liberation and black unity as argued by Gough (1995). Jane Ngwenya (a former Zimbabwean Cabinet Minister) being interviewed in Matshazi (2007: 3) pointed out that " during the colonial days speaking English was one of the many virtues preached on blacks. At that time, at school you could see black students speaking to trees in English in an effort to improve their language and to demonstrate that they were now able to converse in a language of the untouchables." While English functioned as the language of prestige and power, an African language such as Shona was typically maintained as a solidarity code. Bernstein (1994: 412) points out that Shona remained the language of "home, family and ethnic solidarity for it's native speakers." This disadvantaged the development of African languages such as Shona.

A prominent feature of the teaching of indigenous languages, for example, Shona, in colonial schools was the use of English as a reference point(www.//fafunwafoundation.triped.com/fafunwafoundation/id7.html). Thus the grammatical categories of English were applied to African languages. In fact, the meta-language used 
was English, with the result that the teaching and learning of African languages was an extension of the learning of English. As already said above, a very prominent feature of the teaching of indigenous languages such as Shona was the use of English as a reference point. Taking English as a reference language for the teaching of indigenous languages accorded it a high status over them. According to Dube (2000:20) and Magwa (2007) the teaching of word division in Shona had problems that emerged from the translations that were involved in the teaching and learning of Shona at secondary school level.

An enormous stock of English words has been adopted in Shona and the mixing of English and Shona in teaching and learning in secondary schools is perhaps the strongest indication of the impact of English (Gough 1995). Chimhundu (2002) supports this view when he points out those designations in English may influence extensions in meaning of old word forms in Shona to match those in English.

At independence educational reform was high on the agenda in Zimbabwe. English was made an official language to be used in business, education and parliament. Shona was given the same status. Although Shona and Ndebele are now accepted for use in some formal domains, such as in the Senate and as a language of instruction in lower primary education, English continues to dominate as the official language, (Thondhlana 2005). In education, English continues to be the dominant language. The Education Act 1987 (as amended in 1990) states that:

(1) The three main languages of Zimbabwe, namely, Shona, Ndebele and English shall be taught in all primary schools from the first grade as follows:

(a) Shona and English in all areas where the mother tongue of the majority of the residents is Shona or

(b) Ndebele and English in all areas where the majority of the residents is Ndebele.

(2) Prior to the fourth grade, either one of the languages referred to in paragraph (a) or (b) of subsection 1 may be used as the medium of instruction, depending upon which language is more commonly spoken and better understood by pupils.

(3) From the fourth grade, English shall be the medium of instruction provided that Shona and Ndebele shall be taught as subjects on an equal time allocation as the English language.

(4) In areas where minority languages exist, the Minister may authorise the teaching of such languages in primary schools in addition to those specified in subsection (1), (2) and (3) (PartX1 Section 55 page 255).

As shown above, although all the major languages enjoy some degree of prominence under the Act, English continues to enjoy the central role as indicated in subsection (3) in the non-obligatory nature of the early primary school mother tongue instruction. This recognition is largely in word only. According to Thondhlana (2005:33) in Zimbabwe most secondary schools prefer to use English from the outset to ensure their students' proficiency in English, which is considered the language of power and economic well being.

In Zimbabwe, as well as elsewhere in Africa, bilingualism has tended to be a substructure because the socio-cultural attributes of indigenous languages have been denigrated in favour of those of the colonial languages that are considered to be more prestigious. This has even resulted in some Africans, educated through the medium of the colonial language, shunning their mother tongues (Sure \& Webb 2000). It is not surprising therefore that in Zimbabwe secondary schools English continues to dominate the education system.

English remained the medium of instruction in schools and a key qualification for further education. Nziramasanga (1999:161) points out that "English has remained entrenched as the medium of instruction as well as the key to qualifications for education and training at all levels and therefore as the key to employment, upward social mobility and international dialogue." This has accorded English a higher status than Shona. On the other hand a candidate at ' $\mathrm{O}$ ' level who has passed more than five subjects including Shona, but without English, is considered to have an incomplete certificate at ' $\mathrm{O}$ ' level. It should be noted that Shona and Ndebele or any other indigenous languages are not acceptable linguistic substitutes to English. When prospective employers and institutions are inviting candidates or advertising opportunities for further study or vocational purposes they insist that applicants should have passed English at 'O' level ( Mkanganwi 1987 and Chimhundu 1993:57). In this case learning English is instrumental in gaining material needs and this may adversely affect the development of Shona and hence the performance of learners writing Shona examinations in secondary schools in Zimbabwe.

After independence, English continued to dominate in both the electronic and print media. Shona is not being used in the internet, media, medicine etc. In tertiary education and secondary schools, English trained teachers outnumber the Shona trained teachers. This has encouraged the development of English as a language and disadvantaged the development of Shona and compelling teachers and learners of Shona to look down upon their language. In fact, English has established itself in domains such as administration, education, jurisdiction and other government controlled and non-governmental institutions to the extent that it has become a major impediment, a brake or constraint on the promotion and development of African languages (such as Shona) as argued by Mutasa (2003).

During colonial Rhodesia (now Zimbabwe) "the belief that English was a superior language to Shona was certainly there (Ngara 1982:24)". After independence these attitudes continued but most of the school 
children were conscientized to appreciate their own cultures and languages. According to Dube (1997:11) “ these attitudes may have improved at independence but now it would appear they are contributing to the persistence of Shona and English diglossic situations."

\section{Statement Of The Problem}

This research investigates the problems that are experienced in the teaching and learning of Shona in secondary schools within the diglossic relationship between English, as a high variety and Shona as a low variety.

\section{Purpose Of The Study}

This research sought to investigate the problems found in the teaching and learning situations in Zimbabwean secondary schools with regard to Shona and English. The paper aimed to find solutions to the problems of the diglossic relationship of Shona and English in the teaching and learning situations in secondary schools and to suggest ways in which Shona, as a language, could be developed in order to become a high variety language that is truly an official language.

\subsection{Research Design}

\section{Methodology}

The survey design was used to collect data for the study. The survey design was preferred because it is the most appropriate design where self-reported beliefs and opinions are sought (Davis and Sotton 2004).

\subsection{Instrumentation}

Questionnaires were administered to collect data from the Shona teachers and pupils in secondary schools in and around Bulawayo in Zimbabwe. The questionnaires were administered to 100 learners doing ' $O$ ' Level Shona in and around Bulawayo and to 50 teachers who were teaching Shona at secondary schools and other tertiary institutions. Such a sample provided enough information to generalise on the Zimbabwean secondary school population. Interviews with selected Shona writers and 'O' Level public examination makers for Shona were be carried out

\section{Results from the findings}

Findings show that English is used in the teaching of Shona grammar, practical criticism and modern prose in Zimbabwean secondary schools. The main reasons given for the use of English in the teaching and learning of Shona are that English is well developed in grammatical terms and this is not found in Shona. This is supported by Mutasa (2003:302) who pointed out that English is the preferred language for teaching and learning by most parents and university and college students. It is generally assumed that English is inherently superior and better suited for education. Conversely African languages such as Shona are considered inferior and less suited for education. To the Zimbabwean student the advantage of using English as the language of teaching and learning outweighs the merits of employing African languages such as Shona in teaching and learning. This is summarised by Sithole (1989:24) when he says " provision of education in the vernacular rather than an international language (such as English) arouses resentment among students and parents." Reference texts being used to teach Shona grammar and practical criticism are written in both Shona and English. English is more expressive than Shona and it supplements Shona because it is grammatically developed. To reinforce this view Chapanga and Makamani (2006:393) maintain that "Shona does not have vocabulary for use in academic discourse. Areas like phonetics, phonology, morphology, syntax and theories of literature do not have standardised Shona terminology with which they can be taught."

From the above given reasons, the implications of why teachers and students are using English in the teaching and learning situation of Shona may be that Shona is still under developed and this is viewed as an acute short-coming that jeopardizes the use of it in major domains, hence it is difficult for it to be accepted as an official language. This may be one reason why the students may be failing to answer ' $O$ ' level Shona grammatical examination questions. Aspects of Shona such as traditional prose and culture are being taught in Shona. The reason given by respondents is that cultural norms and values are best understood in one's mother tongue. This is supported by Dube (1997: 37) who argues that there is an interrelationship between the content of a language and the beliefs, values, and the needs of the speakers of the language. In other words, culture is best understood in one's language and language is a carrier of one's culture. According to Pattanayak (1981: 55) " instruction in the mother tongue (such as Shona ) helps in the search for self affirmation, establishes group identity, satisfies the national urge for cultural footedness and avoids fanaticism and helps in the concept formation, critical thinking, creativity and imparting social values." Hence there is need to learn traditional prose and culture using Shona. Apart from this, traditional prose and culture have terminologies that are not borrowed from English hence they are easy to be understood. Chiwome (1992:248) in his research, established that learning takes place longer in a foreign language than in one's mother tongue, which means mother tongue 
tuition ensures linguistic accessibility to studied material, helps to develop critical thinking and to foster effective communication. Views about Shona as a medium of instruction in education may be the wish and desires of Zimbabwean teachers and students teaching and learning Shona respectively. Unfortunately it cannot be fulfilled at present because of crippling linguistic and sociolinguistic factors, the central ones being the attitudes of parents, teachers and learners, lack of study material, the view that it is a way of compromising standards and certainly the power of English (Mutasa 2003).

The students indicated that it is better to be competent in English than in Shona. They clearly pointed out that English was a global language used in different countries as a language of communication. Being competent in English in Zimbabwe enhances one's chances of being marketable in industry, education and commerce, almost anywhere. This is supported by Gudhlanga and Makaudze (2005:3) who pointed out that " in order for one to be considered for further education and employment, one had to pass English at 'O' level. Shona and Ndebele where not viewed as acceptable linguistic substitutes." Indeed when prospective employers and institutions are inviting applications or advertising opportunities for further study or vocational purposes, they insist that applicants should have passed English at 'O' level (Dube 1997:39). The overemphasis on passing English at 'O' level adversely affects the interest of the students in doing Shona as a subject. It weakens their concentration on that subject and hence they will fail to produce good results in Shona ' $\mathrm{O}$ ' level examinations. On the other hand, being proficient in English may not imply that one would be good in business, education or commerce if he is employed there. Mutasa (2003:307) supports this argument when he says, "education through the medium of English and the ability to speak the language does not guarantee success socially, economically and politically as most parents think." Is it not a fact that Zimbabweans who have passed English at 'O' level are roaming the streets today? From the above-discussed arguments it would appear that the ability to use English is regarded as a mark of being intelligent. Students take English as a prestigious language variety that enjoys an official language status as opposed to the Shona language.

These respondents also noted that, through borrowing terms from English, Shona created technical terms that ended up being spelt differently and that are difficult to translate or come up with Shona equivalents of some English terms especially in subjects like Science and Mathematics. This is supported by Mutasa (2003:307) when he argued that African languages (such as Shona) are viewed as not adequate as languages of tuition for other subjects because of linguistic deficiency. Shona does not have sufficient vocabulary for use in academic discourse. In other words, Shona is handicapped for it is not in use as a medium for wider communication particularly in professional circles (Masukume 2002).

The teachers in this study noted that the students have seen Shona as an inferior subject to other subjects hence they are demotivated to learn the subject. They look at it as a subject for dull students. Shona is not a regional subject accepted within the SADC region. Time allocated to teach Shona in some secondary schools is unfavourable, sometimes it is in the afternoon when all students are tired. This is supported by Chiwome (1996) and Bamgbose (1991) who argue that the time slots allocated for instruction of indigenous languages was unfavourable. In addition Shona does not have sufficient vocabulary for use in academic discourse and still relies heavily on English in the teaching of grammar and practical criticism. From the reasons that have been given it implies that Shona has a lot of limitations for it to be accepted as a language of instruction. Even if the Shona teachers are motivated to teach the students the above noted factors also play a part in embarrassing the teachers from carrying out their duties. This shows that society still looks down upon Shona. It is a language that lacks prestige and power (Gudhlanga 2005).

The teachers also felt that some aspects of Shona such as practical criticism, grammar and literature should be taught in English noted that Shona is still underdeveloped. Most reference materials used in teaching grammar and practical criticism are written in English; hence it is difficult and confusing to translate them into Shona. Some of them, who still have colonial mentality, argued that these aspects of Shona have been taught in English since the pre-independent period and the students have excelled very well hence there is need for continuity. Such ideas especially from teachers, really downgrade the development of indigenous languages such as Shona and Ndebele and there is need to liberate such teachers from colonial linguistic bondage (Awoniyi 1982). Another reason which these teachers brought was that the created Shona grammatical terms are difficult to comprehend and that English has the linguistic and literary terminology necessary for teaching and learning Shona grammar and practical criticism. This shows how underdeveloped Shona is and that it compels the teachers and students to use English where it would have been to their advantage to use Shona as argued by Dube (1997:35). In addition, they went on to point out that English is prestigious and is seen as a gateway to success. If one is to be considered for further education or employment in Zimbabwe he should be in possession of a pass in English at 'O' level (Viriri 2003). In other words, English becomes a matter of life and death.

However most of the reasons given by the teachers show their negative attitude towards indigenous languages such as Shona and Ndebele. The importance attached to English is too much. Zimbabwe has good artisans who were trained on the job in industry and have failed English at ' $O$ ' Level but are doing very well in industry as argued by Dongozi (2002). The informal sector of Zimbabwe employs most of the workforce the 
majority of whom are not proficient in English, but are doing well. Are they not using Shona as their language of communication at work?

From these responses it implies that within the diglossic relationship between English and Shona, English as a high variety language adversely influences the performance of students in the teaching and learning situation of Shona grammar and other aspects of Shona at secondary school level. It is sad to note that English is being taken as more expressive than Shona and hence the students fail to answer Shona grammar questions in Shona and opt to use English instead. The teachers who indicated that their learners were able to clearly express themselves in Shona when answering Shona grammar ' $O$ ' level questions gave their main reason as that they had successfully taught their students in Shona since they started their secondary school education. Some teachers argued that their students are highly proficient in Shona and don't have problems in expressing themselves in Shona when answering grammatical questions.

The respondents who argued that English is not influencing the performance of Shona students in answering Shona examination questions noted that the Ministry of Education's policy is that Shona students should be taught Shona grammar in Shona. Most of the schools are being forced to use Shona when teaching Shona. It is now compulsory for the candidates at ' $\mathrm{O}$ ' level to answer Shona examination questions in Shona so that there is no way in which English may influence the performance of these candidates sitting for Shona examinations. Even though such plausible arguments may be brought forward it seems the teachers still have the tendency to teach certain aspects of Shona in English and thereby influencing how the students perform when answering Shona examination question as pointed out by Chipanga and Makamani (2006: 391).

It is also important to note that the performance of students in answering Shona ' $\mathrm{O}$ ' level examination questions may not be influenced by English language alone, other factors such as availability of resources, teaching methods, environmental factors and home background may also play an important role. Hence the idea that English influences the performance of students answering Shona examinations may not hold water.

\section{Conclusions}

The Shona students, teachers, lecturers and Shona writers agree that Shona is underdeveloped and this hinders its use in such areas as teaching and learning in secondary schools. This has forced the Shona teachers and learners to use English where it would have been to their advantage to use Shona. In their research Chiwome and Thondhlana(1992) also concluded that some educators still use English to teach African languages such as Shona because they do not have the academic jargon or register for the concepts they teach. It does not have vocabulary for use in academic discourse and areas such as phonetics, phonology, morphology, syntax, and theories of literature do not have standardized Shona terminology with which they can be taught. The use of English in the teaching of Shona is one reason why the learners are failing to answer well ' $\mathrm{O}$ ' level Shona grammar examination questions. It has been found that Shona in its present form is inadequate to be used as a language of instruction.

The research findings also show strong evidence that most reference materials used in teaching Shona grammar and practical criticism are written in English and such a practice downgrades the development of Shona as a language of instruction. The findings of the research indicate that students have difficulties in translating English grammatical terms to their Shona equivalents, hence they end up confused and performing badly when answering Shona ' $\mathrm{O}$ ' level grammar examination questions. In addition English has grammatical terms which Shona does not have, hence it supplements Shona in the teaching of Shona grammar. The teaching of Shona aspects in English determines the way the Shona 'O' level examinations are set and answered and this influences the learners' performance for the Shona ' $O$ ' level examinations.

At school the students are forced to speak in English wherever they are. This ensures that the students become proficient in English rather than Shona. The teachers feel that English as a language of instruction for many subjects should be made compulsory at school to enhance the students' performance. Being competent in English in Zimbabwe enhances one's chances of being marketable in industry, education and commerce. Because Shona is being regarded as a low variety, as compared to English, a high variety, it implies that students will not revise it, and this results in their failure to produce good ' $\mathrm{O}$ ' level Shona examination passes.

The teaching of Shona components in English needs immediate attention. Currently the Ministry of Education and Culture in Zimbabwe is implementing an educational policy that Shona grammar should be taught or learnt in Shona at all levels of education, hence teachers are being compelled to use Shona when teaching Shona. This is a positive step in the development of Shona. ZIMSEC has even moved a step further by making it compulsory that ' $O$ ' level Shona examinations should strictly be answered in Shona. However greater steps need to be made in the provision of Shona resource materials to Shona ' $O$ ' level students. Most of their resource materials are written in English and this has provided problems of translation from English to Shona. On the other hand, the teachers still have the tendency of teaching certain components of Shona in English (Gudhlanga 2005). 
The findings show that the English language is regarded as a language of high status and high variety and inversely, Shona is regarded as a variety of low esteem, too rural and inferior. To the students English is a prestigious language that, unlike Shona, enjoys an official language status transpose it is a waste of time to learn Shona. In order for one to be considered for further education and employment, he/she has to pass English at ' $O$ ' level and Shona is not viewed as a linguistic substitute. The emphasis on passing English at 'O' level adversely affects the interest of students in studying Shona as a subject. It weakens their concentration on that subject and hence they fail to produce good results in Shona ' $O$ ' level examinations. As a result Shona students look at English as a gateway to success and consider Shona as a language that is not economically viable. One may conclude that Shona is not taken seriously and this influences the performance of learners when answering Shona ' $\mathrm{O}$ ' level examination questions. This is a serious attitudinal problem that needs to be addressed.

\section{Recommendations}

The Government should formulate a clearly defined language policy whereby Shona is given equal treatment with English. Currently the Government has its language policy through the provision of the Education Act of 1987 and this is failing to address the negative diglossic relationship between English and Shona.

There is need for the Government to consider Shona as a compulsory subject for further education and employment. African languages such as Shona should be a requirement for entry into universities and other tertiary institutions in the same way English is today. Instituting English and not other languages as the only requirement undermines the development of African people who master all subjects except for English. The requirement of certain level attainment of English to access tertiary education and jobs creates the heaviest waste of human resources. A language awareness campaign is necessary in order to redress such attitudes and restore the dignity of Shona as an indigenous language. Workshops to redress such situations are necessary in order to make people aware of the importance of indigenous languages such as Shona and Ndebele. The students and teachers should appreciate that both languages are important in the development of the economy.

Shona in schools should be taught in Shona. There is need for Human resources development to handle the use of Shona at all levels of education and to handle multilingualism in the teaching and learning situations in schools. Programmes to train teachers to teach Shona in Shona should be designed.

\section{References}

[1]. Adegbija, E.1994. Language attitudes in sub-saharan African: A sociolinguistic overviews. Clevedon: Multi-lingual Matters.

[2]. Awoniyi, T. A.1982.The teaching of African Languages, London: Hodder and Stoughton.

[3]. Bamgbose, A. 1991. Language and the Nation: The language question in sub- saharan Africa. Edinburg: Edinburg University Press.

[4]. $\quad$ Bernstein, J. 1994. English and Shona in Zimbabwe'. In World English. Vol. 13, 411-418.

[5]. Chapanga, E and Makamani, R. 2006. 'Teaching Shona in English/Shona: ideological challenges and implications- whither UZ and MASU?' Zimbabwe Journal of Educational research, Volume 18 No3 p383-397.

[6]. Chimhundu, H. 1993. 'The status of African Languages in Zimbabwe'. SAPEM,_October 1993, 57-59.

[7]. Chimhundu, H. 2002. Adoption and adaptation in Shona. Oslow: ALLEX project.

[8]. Chiwome, E. M. 1996. A social History of the Shona Novel. Effel Flats: Juta Zimbabwe Pvt Ltd.

[9]. Chiwome E. M.\& Thondhalana J. 1989. 'The teaching of Shona through the medium of Shona and English in High schools and at the University of Zimbabwe.' In Zambezia, 1989 xvi(ii).

[10]. Crystal, D. 1996. English as a Global Language. Cambridge: Cambridge University Press.

[11]. Doke, C. M. 1931. A comparative study in Shona phonetics, Jahannesburg: Wits Univesity Press.

[12]. Dongozi, F. 2002. 'Publishers continue to shun minority languages.' The Daily News, 4 April 2002.

[13]. Dube, S. 1997. A study into reasons why Shona as the low variety in a diglossic relationship with English in post-independent Zimbabwe. Unpublished Article-U submitted to the Department of African Languages and Literature at Unisa.

[14]. Dube, S. 2000 An investigation of the current Shona orthography: effects of its limitations and suggested solutions. Unpublished dissertation for MA, Pretoria : University of South Africa.

[15]. Gough, D. H. 1995. Black English in South Africa. Armsterdam: John Benjamins.

[16]. Government of Zimbabwe 1987. Zimbabwean Education Act. Harare: Government Printers.

[17]. Gudhlanga, E. S. 2005. 'Promoting the use and teaching of African Languages in Zimbabwe.' In ZJER 17 No. 1 pp 54-66.

[18]. Gudhlanga, E. S. and Makaudze, G. 2005. 'Promoting the use of African Languages as a medium of instruction of Higher learning in Zimbabwe: the case of MASU's Department of languages, literature and Music.' Paper presented at University of KwaZulu Natal. Durban: 27-29 June 2005.

[19]. Magwa, W. 2007. Chiraidzo chemanyorerwo matsva nemutauro weChishona, muBotswana, muMozambiki, neZimbabwe: mudonzvo womudzidzi. Capetown: Centre for Advanced Studies of African Society.

[20]. Matshazi, N. 2007. 'Heroine Ngwenya narrates how J Z Moyo Died.' In The Sunday News, 11 November 2007.

[21]. Mutasa, D. E. 2003.The Language policy of S. A.: What do people say? Pretoria : Unisa.

[22]. Mkanganwi, K G. 1987 'Linguistics, Language and Zimbabwe'. In LASU Conference Proceedings. Harare. 2-5 September 1986.

[23]. Nziramasanga, C. T. 1999.'Zimbabwe Report of the Presdential Commission of Inquiry into Education and Training to His Excellence the Presdent'. Harare: Government Printing Press.

Pattanayak, D. P. 1981.Multilingualism and mother-tongue in Education. Delhi: Oxford University Press.

[25]. Silva, P.M. 1995.Lexicography for Southern African English. Amsterdam: John Benjamins.

[26]. Sithole, J. 1989.Diglossia in Zimbabwe, Unpublished MA Dissertation. Harare: UZ. 
[27]. Sure, K. \& Webb, V. 2000. African voices. Oxford: Oxford University Press.

[28]. Thondhlana, J. 2005. 'Languages for teaching Using indigenous and learning in Zimbabwe' http://jan.ucc.nau.edu/ iar/ILAC/ILAC_4pdf (accessed 26 November 2006)

[29]. Viriri,V. 2003. 'Language planning: the conservation and management of indigenous languages in Zimbabwe.' Paper presented at ICOMOS 14th General Assembly and Scientific Symposium

[30]. www.fafunwafoundation.triped,com/fafunwafoundation/id7.html accessed 27 June 2005. 